\title{
Education Access Barriers for Girls in South Sulawesi's Coastal Area
}

\author{
Jeanny Maria Fatimah \\ Department of Communication \\ Faculty Social and Political Science \\ Hasanuddin University \\ Makassar, Indonesia \\ jeannyfatimah@gmail.com
}

\author{
Dwia Aries Tina Pulubuhu \\ Department of Sociology \\ Faculty Social and Political Science \\ Hasanuddin University \\ Makassar, Indonesia \\ Arianto \\ Department of Communication \\ Faculty Social and Political Science \\ Hasanuddin University \\ Makassar, Indonesia
}

\begin{abstract}
Buginese Ethnic communities' perspective in coastal area assum that a boy has more "economic value" than girl. Assumption that boy will become head of family and have responsibilities to family, and also become a central figure in family community in Makassar. This research aims to increase the motivation of girls in order to access educations as well as boy. This research use mixed-method method which combine qualitative and quantitative research data. Research subject which become data source is 7-13 years old girl in Paotere village city of Makassar. Data are collected through observation, indepth interview, and questionnaire. This research show that girl motivation is on the moderate position. It's happen because most of parents assume that their son should become a priority compared to their daughter. There $57,1 \%$ parents consider that their son has an obligation to earn a living for their family. Hereafter, assumption that their daughter not preffered because they will go along with her husband and work at home at least. Another assumption, parents state that boys are smarter than girls in school. Negative stereotyping always affects injustice between boys and girls in accessing education. Dominant role of parents and quality of communication are important to hold by parents to motivate their daughter to stay school so they can improve their knowledge and their access to education. Indication that parents awareness to give formal education to their daughter can positively contribute to the positive stereotyping of girls in coastal area to access education as well as boys.
\end{abstract}

Keywords—girls; education access; coastal area

\section{INTRODUCTION}

The circle of poverty is a complex phenomenon, multidimensional and cannot be seen trough absolute number. Wide coatal area and diverse of community cultural cause condition and problems in South Sulawesi become diverse with strong local characters and different poverty experience between women and men.
Referring to Central Bureau of Statistics (BPS) data about the increasing number of the poor in South Sulawesi, really surprising that BPS calculation, number of the poor increase from 832,910 people in March 2011 become 835,510 People in September 2011 or increase 2.600 people $(0.31 \%)$ in the last six month [1]. If we use linearity perspective, this phenomena is really unpredictable consider number of the porr in South Sulawesi consistently decrease in recent years [2]. Although percentage of the poor decrease fro $10.29 \%$ to $10.27 \%$ (it was caused by total number of population increase faster than the poor), increasing of the poor absolute number must be responded seriously.

In Indonesia, UNICEF (2003) identified three important things that need to be improved to enhance gender equity. The three aspects are access to higher level education, against the sexual exploitation, and better heath services for pregnant woman. Actons in this field will directly bring benefit for women. Realization of this program was followed up by ten ministry of education in Southeast Asia, including Indonesia signed Bangkok Declaration on Quality Equality in Education. Bangkok Declaration emphasized the important of improving inclusive and gender responsive education. The signed of the declation is one of the response to the realities of woman unequal opportunity in accessing higher education. Statistic showed that more than 56\% from 104 Million children who cannot access the education is girl, and two-third from 860 Million world population who illiterate is woman [3].

In many region of South Sulawesi can be categorized well in providing education access trough free education program. Level of elementary education participation reaches $97 \%$ both women or man. However, it's still low in higher or advanced education level. Decrease of people who access higher education also followed by the increasing of gender based differentiation.

Reffering data from Ministry of Education explained the reason why girl cannot complete their formal education and 
continue to the higher education [4]. One of the reasons is cultural barrier, culture of early-age marriage for woman in village and coastal area. There is opinion that although woman graduate from higher education, they won't go for working outside because their responsibility to house chores. Different access of unequal gender for girl compared to boy is caused by cultural factor. Our society is still paternalistic which maledominated and male-centered.

Gender inequality phenomenon in accessing education in coastal community still intense. In many families, girl is not become priority to access the formal education. Based the data and phenomena, it is important to study about barrier to girl in accessing education in coastal area.

This research focus is to analyze barrier factors of girls in coastal area to access education. This phenomenon is considered as an impact of gender inequality for woman in coastal area. Woman is only considered as domestic worker without considering their capabilities and gender equality aspect in accessing education.

\section{RESEARCH METHOD}

This research use mixed-method research that combine data both from qualitative or quantitative. Research subject are parent and school-age girl. Selection of qualitative method because this method emphasized breadth and depth, also open possibility for researcher to study specific issues in depth and detail because data collection not restrict only in specific categories [5].

Data collection technique by in-depth interview. Instrument is researcher itself with interview guide. Data is also collected from 35 respondents by questionnaire for 7-13 years old girl. Respondent selection is held in Madrasah Darul Islamiah Al Arabiah MDIT Paotere in Sabutung LR. Riverside Mosque nearby Paotere Fish Market Makassar. Saturated sampling for 7-13 years old girl who access elementary education in that area. Data which collected analyze based on research problem. Next, data is collected, categorized, and conclude premise of this research.

\section{RESULT AND DISCUSSION}

This research result show several barrier factors including cultural, economy, parent's awareness, and awareness on the important of education for woman. All the 35 respondents are from Madrasah Darul Islamiah Al Arabiah MDIT Paotere in Sabutung LR. Riverside Mosque nearby Paotere Fish Market Makassar.

Be based on their parents job, $100 \%$ of them are work as fisherman and freight worker in Paotere Fish Market. Most of Their parent's education level are elementary and junior high school. Data indicates that respondent's parents have low education level. That implicates the awareness of parents to enter their daughter to higher or advanced level of education. This research find there are four factors that become barrier including economy, cultural, education awareness of parents, and education awareness of girl, as in following table 1 :
TABLE I. DISTRIBUTION OF GIRLS EdUCATION ACCESS BARRIER

\begin{tabular}{|c|c|c|c|}
\hline $\begin{array}{c}\text { Girls } \\
\text { Education } \\
\text { Access Barrier }\end{array}$ & $\begin{array}{c}\text { Percentage of } \\
\text { Access }\end{array}$ & $\begin{array}{c}\text { Education } \\
\text { Barrier }\end{array}$ & Total \\
\cline { 2 - 4 } & Yes & Not & \\
\hline $\begin{array}{c}\text { Economy } \\
\text { Aspect }\end{array}$ & $\mathbf{3 5 ( 1 0 0 )}$ & $\mathbf{0}$ & 100 \\
\hline Cultural Aspect & $\mathbf{2 0 ( 5 7 , 1 )}$ & $\mathbf{1 5 ~ ( 4 2 , 8 )}$ & $\mathbf{1 0 0}$ \\
\hline $\begin{array}{c}\text { Education } \\
\text { awareness of } \\
\text { parents Aspects }\end{array}$ & $\mathbf{2 7 ( 7 7 , 1 )}$ & $\mathbf{8 ~ ( 2 2 , 9 )}$ & $\mathbf{1 0 0}$ \\
\hline $\begin{array}{c}\text { Education } \\
\text { awareness of } \\
\text { Child/Girl } \\
\text { Aspects }\end{array}$ & $\mathbf{3 0 ( 8 5 , 7 )}$ & $\mathbf{5 ( 1 4 , 3 )}$ & 100 \\
\hline
\end{tabular}

Source: Primary Data, 2018

Table 1 show that economic factor become the most dominant factor for them to continue their education to the higher level, the percentage is 35\%. The low-income parent implicate to economic inability to finance their children education cost. To overcome that problem, they have to minimalize access for their daughter to decent education as well as boy. Economic barrier is limitation of financial to afford educational cost so that poor family perforce to pick the boys of girl.

Cultural factor also contribute to minimize girl access to education if compared with the boys. Based on research data show that 20 respondents $(57.1 \%)$ have opinion that cultural aspects become barrier factor for them to continue their education to the higher level. Only 8 respondents (22.9\%) assume that cultural factor no longer barrier for woman in getting same rights for education. Woman Poverty problem can be found in patriarchal culture which man become superior and woman become subordinate. Patriarchal culture can be seen in family life, community, and become source of justification in gender bias resource distribution.

The awareness level of education importance in children itself also become barrier factor in improve access to education for woman in coastal area. Research data show that 30 respondents (85.7\%) who assume that education is important for their future and only 5 respondents think that education is not important. This condition is caused by community perspective that assume boys have higher "economic value" so that majority of parents tend to prioritize their son to access the education. Moreover, there is strong assumption that their son will be the head of family, become responsible person in family and central figure in community. Gender injustice also can be seen in formal education, realize or not, parents directly give a role and opportunity to their son.

\section{CONCLUSION}

Factor of education access barrier for girl in South Sulawesi Coastal Area can be categorized in four factors: economic, cultural, parent awareness, and children awareness. Cultural factor, parents give more priority to their son in education because they assume boys will become head of 
family and earn a living for their family. Next, assumption those girls do not need to prioritize because they will follow their husband and stay in domestic work. Negative stereotyping always cause injustice between girls and boys to access education. Government must be actively involved to eradicate gender gap in education by improving education quality and relevance so that community can assess that education can give value-added comparable to the cost. Providing education services in family widely and diverse so that can be accessed by all parents in coastal area of Indonesia. Availability of education infrastructure must be provided nearby coastal area to reduce educational cost and reluctance of children in accessing school.

\section{ACKNOWLEDGMENT}

Research grant is financed by Kemristek DIKTI and LP2M Hasanuddin University 2018. Thanks to Madrasah Darul Islamiah Al Arabiah MDIT Paotere in Sabutung LR. Riverside Mosque nearby Paotere Fish Market Makassar who facilitate data collection of this research.We would like to thank the provincial/regency/ municipality governments in South Sulawesi, especially to the teachers who are very helpful in providing information for the advancement of education. Finally, to all those who contribute to this research process.

\section{REFERENCES}

[1] BPS, Data Pertumbuhan Ekonomi Regional Bruto Menurut Kabupaten/Kota Provinsi Sulawesi Selatan Tahun 2010-2014 [Regional Gross Economic Growth according to Regency/City of South Sulawesi Province, 2010-2014], 2014.

[2] Agussalim, Memaknai Angka Kemiskinan Sulawesi Selatan [Interpreting Poverty Rate of South Sulawesi]. Makassar: Nala Cipta Litera and PSKMP UNHAS, 2012.

[3] UNESCO, Gender and Education for All:The Leap to Equality (EFA Global Monitoring Report, 2003/04), 2003.

[4] E. Noerdin, E. Agustini, D. T. Pakasi, S. Aripurnami, S. N. Hodijah, and L. Hadiz (Ed.), Portrait of Women Poverty. Jakarta: Women Research Institute, 2010.

[5] J. W. Creswell, Research Design: Qualitative and Quantitative Approaches. Thousand Oaks: Sage Publications Inc., 1994. 
